Scientia Marina 71(1)

March 2007, 19-28, Barcelona (Spain)

ISSN: 0214-8358

\title{
Decapod crustacean assemblages off the West coast of central Italy (western Mediterranean)
}

\author{
EMANUELA FANELLI ${ }^{1}$, FRANCESCO COLLOCA ${ }^{2}$ and GIANDOMENICO ARDIZZONE ${ }^{2}$ \\ ${ }^{1}$ IAMC-CNR Marine Ecology Laboratory, Via G. da Verrazzano 17, 91014 Castellammare del Golfo (Trapani) Italy. \\ E-mail: e.fanelli@iamc.cnr.it \\ ${ }^{2}$ Department of Animal and Human Biology, University of Rome "la Sapienza", V.le dell’Università 32, 00185 Rome, Italy.
}

\begin{abstract}
SUMMARY: Community structure and faunal composition of decapod crustaceans off the west coast of central Italy (western Mediterranean) were investigated. Samples were collected during five trawl surveys carried out from June 1996 to June 2000 from 16 to $750 \mathrm{~m}$ depth. Multivariate analysis revealed the occurrence of five faunistic assemblages: 1) a strictly coastal community over sandy bottoms at depths $<35 \mathrm{~m} ; 2$ ) a middle shelf community over sandy-muddy bottoms at depths between 50 and $100 \mathrm{~m} ; 3)$ a slope edge community up to $200 \mathrm{~m}$ depth as a transition assemblage; 4) an upper slope community at depths between 200 and $450 \mathrm{~m}$, and 5) a middle slope community at depths greater than $450 \mathrm{~m}$. The existence of a shelfslope edge transition is a characteristic of the western and central Mediterranean where a Leptometra phalangium facies is found in many areas at depths between 120 and $180 \mathrm{~m}$. The brachyuran crab Liocarcinus depurator dominates the shallow muddy-sandy bottoms of the shelf, while Parapenaeus longirostris is the most abundant species from the shelf to the upper slope assemblage. The dominant species on the middle slope are mainly nektobenthic (Aristeus antennatus, Aristaeomorpha foliacea, Plesionika martia), bentho-pelagic (Pasiphaea sivado) and benthic species (Nephrops norvegicus). The average diversity of the five assemblages defined increased with depth and the highest diversity values were found in the slope assemblages. Depth is the main factor influencing decapod assemblage composition, but sediment type and dissolved organic matter seem to be secondary structuring factors particularly in the shelf zone.
\end{abstract}

Keywords: distribution, assemblages, Decapoda, Mediterranean.

RESUMEN: ASOCIACIONES DE CRUSTÁCEOS DECÁPOdOS EN LA COSTA OESTE DE ITALIA CENTRAL (MEDITERRÁNEO OCCIDENTAL. - Se ha estudiado la estructura de la comunidad y la composición faunística de crustáceos decápodos en la costa oeste de Italia central (Mediterráneo occidental). Las muestras fueron tomadas durante cinco campañas de prospección pesquera demersal llevadas a cabo entre Junio 1996 y Junio 2000 a profundidades comprendidas entre 16 y 750 m de profundidad. Análisis multivariantes mostraron la presencia de cinco asociaciones faunísticas: 1) una comunidad estrictamente costera sobre fondos de arena a profundiades $<35 \mathrm{~m} ; 2$ ) una comunidad de la plataforma continental media sobre fondos arenosofangosos a profundidades comprendidas entre 50 y $100 \mathrm{~m} ; 3$ ) una comunidad del borde de la plataforma continental hasta los 200 m, como asociación de transición; 4) una comunidad de talud superior entre 200 y 450 m, y 5) una comunidad del talud medio a profundidades superiores a $450 \mathrm{~m}$. La existencia de una transición plataforma-talud es una característica del Mediterráneo occidental y central, en la que la facies de Leptometra phalangium se encuentra en muchas áreas a profundidades comprendidas entre 120 y $180 \mathrm{~m}$. El cangrejo braquiuro Liocarcinus depurator domina en los fondos someros fangoso-arenosos de la plataforma continental, mientras que Parapenaeus longirostris es la especie más abundante desde la plataforma continental hasta la asociación del talud superior. Las especies dominantes en el talud medio son principalmente nectobentónicas (Aristeus antennatus, Aristaeomorpha foliacea, Plesionika martia), bentopelágicas (Pasiphaea sivado) y bentónicas (Nephrops norvegicus). La diversidad media de las cinco asociaciones definidas aumenta con la profundidad, encontrándose los valores máximos de diversidad en las asociaciones del talud continental. La profundidad es el principal factor influyente sobre la composición de las asociaciones de crustáceos decápodos, pero el tipo de sedimento y el contenido en materia orgánica parecen ser factores estructurales secundarios, particularmente en la plataforma continental.

Palabras clave: distribución, asociaciones, Decapoda, Mediterráneo. 


\section{INTRODUCTION}

Decapod crustaceans are a dominant or subdominant faunal component in temperate to subtropical assemblages, such as the Mediterranean Sea, and constitute a key taxon linking lower and higher trophic levels (Wenner and Boesch, 1979; Fariña et al., 1997; Cartes, 1998). In the Mediterranean, they are one of the dominant groups of megabenthic invertebrates on the continental shelf and slope and a very important fraction of demersal communities (Abelló et al., 1988; Maynou and Cartes, 2000; Colloca et al., 2003). The distribution and abundance of decapod crustacean species have been investigated in detail in the north-west basin (Abelló et al., 1988; Cartes and Sardà, 1993; Maynou and Cartes, 2000), particularly on the continental slope (Cartes, 1993; Cartes et al., 1994; Sardà et al., 1994). No data on the crustacean assemblages have been published from central and eastern Mediterranean areas. In Italian waters (western Mediterranean), Arena and Li Greci (1973), Relini (1981) and Tunesi (1986) investigated the quantitative composition of the decapod crustacean fauna occurring in trawlable fishing grounds.

Demersal fauna off the central-western coasts of Italy is exploited by an intensive trawl fishery targeting both commercial fish and invertebrates. Studies on demersal assemblage distribution in this area demonstrated the importance of several crustacean species (Biagi et al., 2002; Colloca et al., 2003) due to their abundance. The main purpose of this study is to examine the faunistic composition and the main decapod crustacean assemblages occurring off the west coast of Central Italy. The factors that may affect species distribution are also discussed.

\section{MATERIAL AND METHODS}

\section{Study area and data collection}

This study was carried out within the framework of the Mediterranean International Trawl Survey (MEDITS) (Bertrand et al., 2002). A total of five bottom trawl surveys were carried out during the summers (June-July) of 1996 to 2000. The area investigated covered $15,289 \mathrm{~km}^{2}$ off the west coast of central Italy (western Mediterranean) between 16 and $750 \mathrm{~m}$ depth (Fig. 1). The project used a randomized stratified sampling design based on depth

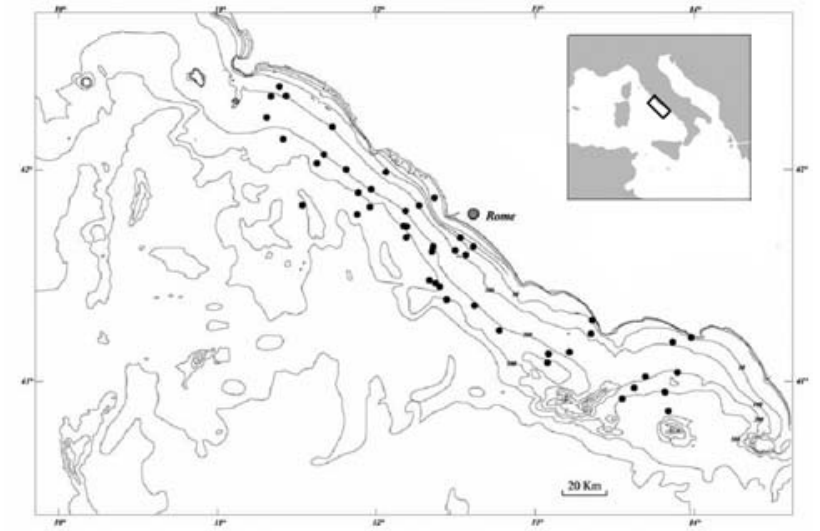

FIG. 1. - Map of the study area and positions of trawl stations in the MedITS project off the central-western coasts of Italy (western Mediterranean ) during 1996-2000.

(five bathymetric strata: 10-50, 51-100, 101-200, 201-500 and 501-700 m) and area. The depth limits were adopted to best cover the distribution areas of the most exploited, or potentially exploitable, species. Locations of stations were selected randomly within each bathymetric stratum at the beginning of the project (1994). Over the following years, a total of 46 fixed stations were sampled in day-time hours (6.00 a.m. to 6.00 p.m.) (Bertrand et al., 2002). Haul duration varied according to depth: 30 min at depths of less than $200 \mathrm{~m}$ and $60 \mathrm{~min}$ deeper than $200 \mathrm{~m}$. All the surveys were carried out with the same otter bottom trawler using a net with a cod end stretched mesh size of $10 \mathrm{~mm}$. The towing speed of the vessels was about 3.0 knots. The distance covered by the net on the bottom was calculated using GPS positions when the net reached and left the bottom. The mean opening of the net mouth was directly calculated for most of the hauls by a commercial SCANMAR system. The swept area was then obtained by multiplying the mean mouth opening of the net by the towing distance.

In the study area, the continental shelf extends up to $120-150 \mathrm{~m}$ depth covering a distance of $15-30 \mathrm{~km}$ from the shoreline. The limit between the upper and middle slope ranges between 400 and $500 \mathrm{~m}$ depth (Carpine, 1970; Relini et al., 1986). The temperature of $13^{\circ} \mathrm{C}$ is generally constant down to $120-200 \mathrm{~m}$ depth (Ifremer, 1997). A layer of Levantine intermediate water, characterized by maximal salinity, flows anticlockwise along the slope between 250 and 700 $m$ depth (Serravall and Cristofalo, 1999). Temperature and salinity are even more stable $\left(12.8^{\circ} \mathrm{C} ; 38.4 \mathrm{psu} \mathrm{S}\right)$ in the deep-sea water masses of the Mediterranean (Reyss, 1971). 
Data on the main macro-epibenthic species found for each assemblage are available in Colloca et al. (2003). Based on grain size composition, according to Emylianov and Schimkus (1986), the continental shelf shallower than $50 \mathrm{~m}$ is characterized by sand (1-0.1 mm fraction dominates), aleuritic $(0.1-0.001 \mathrm{~mm})$ and pelitic $(<0.001 \mathrm{~mm}$ fraction dominates) sediments are found between 50 and 100 $\mathrm{m}$, and bottom sediments are mainly composed of pelitic muds below $100 \mathrm{~m}$.

The study area presents a heterogeneous sedimentary situation which is strongly influenced by terrigenous contributions from several rivers. The northern part is supplied by sediments from the Fiora, Marta, Mignone and Arrone rivers. The sediment type is mainly sandy-clayey (A.A.V.V., 1985). Wave action distributes sediments based on textural characteristics: sandy and sandy-clayey bottoms typify the coastal zone with an increase in the muddy-clayey fraction off-shore (Tortora, 1989). The central part is dominated by the deltic cusp of the Tiber River. The distribution of sediments is the same as on the right side of the Tiber, but in this area the limit between sandy-muddy and pelitic sediments is located at $70-90 \mathrm{~m}$ depth (Bellotti and Tortora, 1985). In the central part, grain size strongly decreases, while in the southern part of the central area it increases due to the strong hydrodynamics and the steep bottoms. In the southern part of the study area fine sands are located shallower than 20$30 \mathrm{~m}$ depth. Finally, the Gulf of Gaeta is influenced by the Garigliano River contribution. In this area, sedimentation is more homogeneous and reaches the highest rates and the highest thickness of the Latium coasts (Chiocci and La Monica, 1999).

\section{Analysis of abundance data}

Abundance index data (Number $\mathrm{km}^{-2}$ ) of decapod crustaceans obtained during the five trawl surveys were pooled in a matrix of species abundance according to station and survey. A Bray-Curtis similarity matrix was then constructed to perform a cluster analysis and a non-parametric multidimensional scaling ordination (nMDS) using PRIMER v5 software (Clarke and Warwick, 1994).

An analysis of similarities (ANOSIM) was used to test the significance of species assemblage differences between trawl surveys (Clarke, 1993). This test assesses significant differences between groups of replicates against a series of random simulations, so that a test statistic (R) is calculated. The R-statistic value, which describes the extent of similarity between each pair in the ANOSIM analysis, can range between 1, when two groups, surveys in this case, are entirely separated and 0 if there is no difference between the two groups.

Since no significant differences between surveys were found in the structure of the assemblages, the data were pooled and average species abundances in relation to trawl station were calculated. An nMDS was then performed on a Bray-Curtis dissimilarity matrix based on average species abundance in relation to trawl station. Uncommon species that were seldom present (which appeared once or twice during the whole sampling period) or exhibited low abundance levels were not included in the data matrix.

The SIMPER procedure (Similarity Percentage analysis) was used to identify those species that characterize each demersal assemblage and those responsible for discriminating between assemblages (Clarke, 1993).

The structure of decapod assemblages was analyzed using community descriptors to obtain a general view. The diversity of each identified assemblage was calculated using Hill's index (N1) as a univariate measure of the species diversity (Hill, 1973). This index, which is the exponential of the Shannon-Wiener function (exp $\left.H^{\prime}\right)$, has already been used in studies on fish assemblages (Greenstreet and Hall, 1996; Blanchard, 2001). Margalef's index (D) was used to assess the species richness of each assemblage. One-way analysis of variance (ANOVA) was used to test if differences between the diversity indexes of the assemblages were significant, based on biomass data. We also calculated Spearman's correlation coefficients between assemblages and the projections of species per haul along dimensions 1 and 2 of MDS. The variables were: depth, latitude and longitude.

\section{RESULTS}

During the trawl survey a total of 53 species of decapod crustaceans were sampled, most of them belonged to the Caridea and Penaeoidea. Only 5 species of Anomura and 12 of Brachyura were collected during the sampling period (Table 1).

The pair-wise test comparisons (ANOSIM) performed on catch data obtained in each survey showed a low level of overlap between surveys: the pair-wise 
TABLE 1. - Decapod crustacean species collected by trawling off the central-western coasts of Italy (central Mediterranean). Depth range of occurrence during the sampling period is also reported

\begin{tabular}{|c|c|c|c|}
\hline & $\underset{(\mathrm{m})}{\text { depth range }}$ & & $\underset{(\mathrm{m})}{\text { depth range }}$ \\
\hline Suborder Dendrobranchiata & & Infraorder Astacidea & \\
\hline Superfamily Penaeoidea & & Family Nephropidae & \\
\hline Family Aristeidae & & Nephrops norvegicus (Linnaeus, 1758) & $286-635$ \\
\hline $\begin{array}{l}\text { Aristaeomorpha foliacea (Risso, 1827) } \\
\text { Aristeus antennatus (Risso. 1816) }\end{array}$ & $\begin{array}{l}367-760 \\
501-760\end{array}$ & $\begin{array}{l}\text { Infraorder Thalassinidea } \\
\text { Family Axiidae }\end{array}$ & \\
\hline Funchalia woodwardii (Johnson, 1867) & 760 & Calocaris macandreae $($ Bell, 1846) & $161-260$ \\
\hline Gennadas elegans (S.I. Smith, 1884) & $515-760$ & Infraorder Palinura & \\
\hline Family Penaeidae & & Family Polychelidae & \\
\hline Melicertus kerathurus (Forksal, 1775) & 39 & Polycheles typhlops (Heller, 1862) & $155-760$ \\
\hline Parapenaeus longirostris (H. Lucas, 1846) & $82-445$ & Family Scyllaridae & \\
\hline Family Solenoceridae & & Scyllarides latus (Latreille, 1803) & 23 \\
\hline Solenocera membranacea (Risso, 1816) & $95-556$ & Infraorder Anomura & \\
\hline Superfamily Sergestoidea & & Family Diogenidae & \\
\hline Family Sergestidae & & Dardanus arrosor (Herbst, 1796) & 23 \\
\hline Sergestes arcticus (Krøyer,1855) & $500-555$ & Family Paguridae & \\
\hline Sergia robusta (S.I. Smith, 1882) & $501-760$ & Pagurus alatus Fabricius, 1775 & 555 \\
\hline Suborder Pleocyemata & & Pagurus excavatus (Herbst, 1791) & $82-225$ \\
\hline Infraorder Caridea & & Pagurus prideaux Leach, 1815 & $32-44$ \\
\hline Family Pasipheidae & & Anapagurus laevis (Bell, 1846) & $44-65$ \\
\hline Pasiphaea multidentata (Esmark, 1816) & $469-760$ & Family Galatheidae & \\
\hline Pasiphaea sivado (Risso, 1816) & $367-627$ & Munida intermedia A. Milne Edwards and Bouvier, 1899 & $9286-586$ \\
\hline Family Alpheidae & & Munida tenuimana G.O. Sars, 1872 & $501-600$ \\
\hline Alpheus glaber (Olivi, 1792) & $32-400$ & Infraorder Brachyura & \\
\hline Family Hippolitidae & & Family Homolidae & \\
\hline Ligur ensiferus (Risso, 1816$)$ & 556 & Paromola cuvieri (Risso, 1816) & $600-635$ \\
\hline Family Processidae & & Family Dorippidae & \\
\hline Processa canaliculata (Leach, 1815) & $286-550$ & Medorippe lanata (Linnaeus, 1767) & $15-306$ \\
\hline Processa edulis (Leach, 1816) & 208 & Family Latreillidae & \\
\hline Processa nouveli Al-Adhub \& Williamson, 1975 & $105-585$ & Latreillia elegans Roux, 1830 & 32 \\
\hline Processa robusta (Nouvel and Holthuis, 1957) & 15 & Family Majidae & \\
\hline Family Pandalidae & & Macropodia longipes (A. Milne Edwards & 184 \\
\hline Chlorotocus crassicornis (Costa, 1871) & $95-469$ & and Bouvier, 1899) & \\
\hline Plesionika acanthonotus (S.I. Smith, 1882) & $286-760$ & Maja squinado (Herbst, 1788) & $106-430$ \\
\hline Plesionika antigai Zariquiey Álvarez, 1955 & $184-500$ & Family Parthenopidae & \\
\hline Plesionika edwardsii (Brandt, 1851) & $260-501$ & Parthenope macrochelos (Herbst, 1790) & $32-260$ \\
\hline Plesionika gigliolii (Senna, 1903) & $286-600$ & Family Geryonidae & \\
\hline Plesionika heterocarpus (Costa, 1871) & 184-394 & Geryon longipes A. Milne edwards, 1881 & $550-760$ \\
\hline Plesionika martia (A. Milne Edwards, 1883) & $367-760$ & Family Portunidae & \\
\hline Plesionika narval (Fabricius, 1787) & $260-501$ & Bathynectes longipes (Risso, 1816) & 87 \\
\hline Family Crangonidae & & Bathynectes maravigna (Prestandrea, 1839) & 556 \\
\hline Philocheras echinulatus (M. Sars, 1861) & $500-555$ & Liocarcinus depurator (Linnaeus, 1758) & $15-394$ \\
\hline Aegaeon cataphractus (Olivi, 1792) & $23-65$ & Macropipus tuberculatus (Roux, 1830) & $95-600$ \\
\hline Aegaeon lacazei (Gourret, 1887) & $38-760$ & Family Goneplacidae & \\
\hline Pontophilus norvegicus (M. Sars, 1861) & $445-469$ & Goneplax rhomboides (Linnaeus, 1758) & $15-394$ \\
\hline Pontophilus spinosus (Leach, 1815) & $367-515$ & & \\
\hline
\end{tabular}

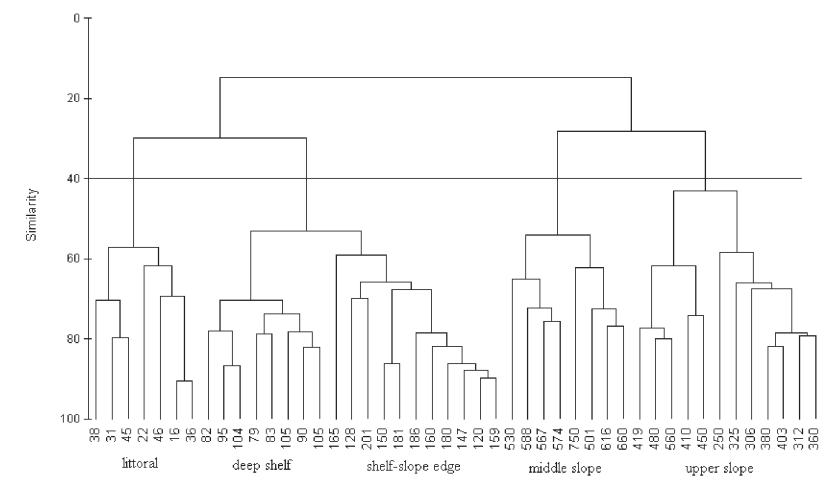

FIG. 2. - Dendrograms of trawl stations using group-average clustering from Bray-Curtis similarity on average abundance of decapod crustaceans obtained during 1996-2000 surveys off the centralwestern coasts of Italy. Mean depth of each sample is given. The upper line indicates groups at the $40 \%$ level of similarity.

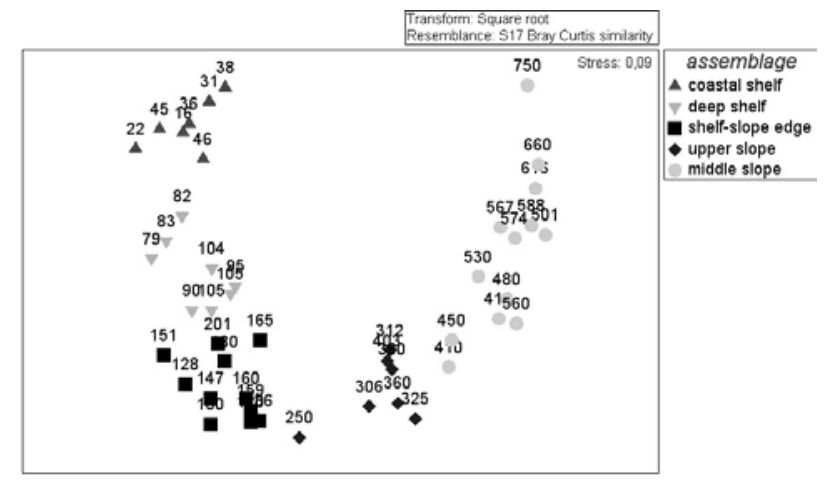

FIG. 3. - MDS ordination plot of average abundance data of decapod crustaceans obtained during 1996-2000 surveys off the centralwestern coasts of Italy. Numbers above labels indicate the mean depth of each sample. 
$\mathrm{R}$ values ranged between 0.05 and 0.40 , which indicates a very low segregation level between surveys.

The dendrogram of similarities among stations showed that five main groups can be clearly defined along the bathymetric gradient (Fig. 2). The first branching of the similarity tree clearly discriminates between shelf and slope stations. The shelf group can be further sub-divided respectively into coastal shelf stations on sandy bottoms (7 trawl stations, mean depth $33.4 \mathrm{~m}, \mathrm{SD}=11.3$ ), middle-shelf stations on muddy bottoms (10 stations, mean depth $96.7 \mathrm{~m}$, $\mathrm{SD}=12.7)$ and shelf-slope edge stations on muddydetritic bottoms (9 stations, mean depth $160.7 \mathrm{~m}$, $\mathrm{SD}=26.4)$. There are two main groups on the slope, which join respectively upper slope stations (7 stations, mean depth $333.7 \mathrm{~m} ; \mathrm{SD}=51.6)$ and middle slope stations (13 stations, mean depth $546.5 \mathrm{~m}$; $\mathrm{SD}=97.1)$. The bathymetrical division between the coastal and the shelf group is located at about $35 \mathrm{~m}$, while the division between shelf and slope is at about $180 \mathrm{~m}$. The limits between the upper and the middle slope are located at about $400 \mathrm{~m}$ depth. Identified assemblages were also separated in nMDS analysis (Fig. 3). A counter-clockwise increase in depth related to a horseshoe effect can be seen in the distribution of trawl stations in the nMDS analysis. The nMDS shows depth as the first key factor, but the horseshoe effect may denote the
TABLE 2. - Analysis of similarities (ANOSIM) performed on the groups identified by cluster and nMDS analysis. Sample statistic (Global R): 0.826; Significance level of sample statistic: $0.1 \%$; Number of permutations: 999 (Random sample from a large number); Number of permuted statistics greater than or equal to Global R: 0 .

\begin{tabular}{lcc}
\hline Groups & $\begin{array}{c}\mathrm{R} \\
\text { Statistic }\end{array}$ & $\begin{array}{c}\text { Significance } \\
\text { level \% }\end{array}$ \\
\hline coastal shelf, deep shelf & 0.679 & 0.1 \\
coastal shelf, shelf-slope edge & 1 & 0.1 \\
coastal shelf, upper slope & 0.996 & 0.2 \\
coastal shelf, middle slope & 1 & 0.1 \\
deep shelf, shelf-slope edge & 0.676 & 0.1 \\
deep shelf, upper slope & 0.820 & 0.1 \\
deep shelf, middle slope & 0.994 & 0.1 \\
shelf-slope edge, upper slope & 0.721 & 0.1 \\
shelf-slope edge, middle slope & 0.987 & 0.1 \\
upper slope, middle slope & 0.707 & 0.1 \\
\hline
\end{tabular}

existence of a structuring factor that is dependent on depth. This is probably a sedimentary factor that represents a gradient of increasingly fine particles (fine silt and mud) in sediments. The stations were distributed gradually from the coastal sandy-detritic bottoms to muddy detritic bottoms on the slope edge. The pair-wise comparisons between groups (Table 2) defined by multivariate analysis showed high separation between assemblages $(\mathrm{R}=0.83)$.

With regards to spatial and bathymetric distribution of decapod assemblages, out of the explored variables, decapods were highly correlated to depth

TABLE 3. - Decapod crustaceans collected from different depth strata listed in rank order of decreasing relative frequency. Only those species appearing in more than half of the trawls made within each stratum have been included.

\begin{tabular}{|c|c|c|c|}
\hline $0-50 \mathrm{~m}$ & $51-100 \mathrm{~m}$ & $101-150 \mathrm{~m}$ & $151-200 \mathrm{~m}$ \\
\hline $\begin{array}{l}\text { Liocarcinus depurator } \\
\text { Medorippe lanata } \\
\text { Goneplax rhomboides } \\
\text { Aegaeon cataphractus }\end{array}$ & $\begin{array}{l}\text { Liocarcinus depurator } \\
\text { Medorippe lanata } \\
\text { Parapenaeus longirostris } \\
\text { Goneplax rhomboides }\end{array}$ & $\begin{array}{l}\text { Parapenaeus longirostris } \\
\text { Liocarcinus depurator } \\
\text { Goneplax rhomboides } \\
\text { Macropipus tuberculatus } \\
\text { Solenocera membranacea } \\
\text { Chlorotocus crassicornis }\end{array}$ & $\begin{array}{l}\text { Parapenaeus longirostris } \\
\text { Macropipus tuberculatus } \\
\text { Chlorotocus crassicornis } \\
\text { Solenocera membranacea }\end{array}$ \\
\hline $201-300 \mathrm{~m}$ & $301-500 \mathrm{~m}$ & $501-750 \mathrm{~m}$ & \\
\hline $\begin{array}{l}\text { Parapenaeus longirostris } \\
\text { Plesionika heterocarpus } \\
\text { Plesionika antigai } \\
\text { Plesionika edwardsii } \\
\text { Macropipus tuberculatus } \\
\text { Chlorotocus crassicornis } \\
\text { Solenocera membranacea }\end{array}$ & $\begin{array}{l}\text { Pasiphaea sivado } \\
\text { Nephrops norvegicus } \\
\text { Parapenaeus longirostris } \\
\text { Plesionika edwardsii } \\
\text { Aristaeomorpha foliacea } \\
\text { Macropipus tuberculatus } \\
\text { Plesionika gigliolii } \\
\text { Plesionika heterocarpus } \\
\text { Plesionika antigai } \\
\text { Aristeus antennatus } \\
\text { Plesionika martia } \\
\text { Solenocera membranacea } \\
\text { Munida intermedia } \\
\text { Chlorotocus crassicornis }\end{array}$ & $\begin{array}{l}\text { Aristaeomorpha foliacea } \\
\text { Plesionika martia } \\
\text { Nephrops norvegicus } \\
\text { Aristeus antennatus } \\
\text { Geryon longipes } \\
\text { Polycheles typhlops } \\
\text { Plesionika acanthonotus } \\
\text { Pasiphaea sivado } \\
\text { Gennadas elegans } \\
\text { Pasiphaea multidentata } \\
\text { Parapenaeus longirostris } \\
\text { Plesionika gigliolii } \\
\text { Macropipus tuberculatus } \\
\text { Solenocera membranacea } \\
\text { Munida tenuimana } \\
\text { Munida intermedia } \\
\text { Aegaeon lacazei }\end{array}$ & \\
\hline
\end{tabular}


(Spearman coefficient $\mathrm{r}=0.951, \mathrm{p}<0.001$ ), and a quasi-significant correlation was found with latitude $(\mathrm{r}=-0.281, \mathrm{p}=0.0581)$.

The most frequent species differed between depth strata (Table 3): Liocarcinus depurator and Medorippe lanata were the most abundant species between 0 and $100 \mathrm{~m}$ depth. The pink shrimp Parapenaeus longirostris dominated from 100 to $300 \mathrm{~m}$ depth, below these depths Norway lobster Nephrops norvegicus, pasipheids, aristeids and pandalids showed the highest values of occurrence.

Table 4 shows the percentage contribution of the main contributor species to within-group similarity calculated for the assemblages identified in the survey. Thus, Liocarcinus depurator and Medorippe lanata were the main contributors in the shelf-sand assemblage. Parapenaeus longirostris was the most typifying species in both the shelf-mud $(65.7 \%)$ and the upper slope assemblages (31.1\%). Nephrops norvegicus (17.6\%), Macropipus tuberculatus $(15.3 \%)$ and three species of pandalid shrimps contributed to defining the upper-slope assemblage. The most typical species of the middle-slope assemblage

TABLE 4. - Percentage contribution of typifying species (over $2 \%$ ) to within-group similarity for the identified demersal assemblages during 1996-2000 trawl surveys off the central-western coasts of Italy

\begin{tabular}{|c|c|}
\hline Coastal shelf & Deep shelf \\
\hline Average similarity: 62.88 & Average similarity: 69.44 \\
\hline Species $\quad$ Contrib\% & Species Contrib\% \\
\hline Liocarcinus depurator $\quad 40.83$ & Parapenaeus longirostris 45.56 \\
\hline Medorippe lanata & Medorippe lanata $\quad 27.70$ \\
\hline Aegaeon lacazei & Liocarcinus depurator \\
\hline Pagurus prideaux & \\
\hline Shelf-slope edge & Upper slope \\
\hline Average similarity: 72.12 & Average similarity: 67.84 \\
\hline Species $\quad$ Contrib\% & Species Contrib\% \\
\hline Parapenaeus longirostris 74.27 & Parapenaeus longirostris 31.57 \\
\hline \multirow[t]{5}{*}{ Macropipus tuberculatus 18.48} & Macropipus tuberculatus 17.90 \\
\hline & Nephrops norvegicus $\quad 15.72$ \\
\hline & Plesionika antigai $\quad 11.14$ \\
\hline & Plesionika heterocarpus 9.95 \\
\hline & $\begin{array}{ll}\text { Plesionika gigliolii } & 4.19\end{array}$ \\
\hline
\end{tabular}

Middle slope

$\begin{array}{lr}\text { Average similarity: } 52.13 & \\ \text { Species } & \text { Contrib\% } \\ \text { Aristaeomorpha foliacea } & 28.16 \\ \text { Nephrops norvegicus } & 24.16 \\ \text { Plesionika martia } & 12.00 \\ \text { Pasiphaea sivado } & 9.04 \\ \text { Polycheles typhlops } & 5.55 \\ \text { Aristeus antennatus } & 3.86 \\ \text { Plesionika acanthonotus } & 2.91 \\ \text { Plesionika gigliolii } & 2.79 \\ \text { Geryon longipes } & 2.57 \\ \end{array}$

TABLE 5. - Average number of species (S), Species richness (D), Species diversity by Hill's index (N1) for each of the five assemblages of decapod crustaceans distinguished by cluster analysis off the central-western coasts of Italy. S.D.: standard deviation

\begin{tabular}{lcccccc}
\hline Assemblage & $\mathrm{S}$ & $\mathrm{SD}$ & $\mathrm{D}$ & $\mathrm{SD}$ & $\mathrm{N} 1$ & $\mathrm{SD}$ \\
\hline coastal shelf & 5.14 & 1.07 & 3.58 & 2.26 & 2.76 & 0.36 \\
deep shelf & 5.20 & 1.69 & 5.40 & 8.90 & 2.44 & 0.76 \\
shelf-slope edge & 4.67 & 2.35 & 2.18 & 1.11 & 1.59 & 0.42 \\
upper slope & 14.86 & 3.76 & 4.14 & 0.96 & 4.24 & 1.05 \\
middle slope & 16.77 & 3.09 & 4.24 & 1.13 & 4.56 & 1.23 \\
\hline
\end{tabular}

TABLE 6. - Results of ANOVA performed on Hill's index of five groups identified by multivariate analysis $(\mathrm{p}<0.0001)$.

\begin{tabular}{llcll}
\hline Source of variation & Sum of squares & d.f. & Mean squares & F \\
& & & & \\
\hline between & 62.11 & 4 & 15.53 & 19.77 \\
error & 32.21 & 41 & 0.7855 & \\
total & 94.31 & 45 & & \\
& & & & \\
\hline
\end{tabular}

were Aristaeomorpha foliacea (30\%), Nephrops norvegicus (22.8\%) and Plesionika martia (13.2\%).

The average diversity, according to Hill's index (NI) (Table 5), decreased from the coastal shelf to the shelf-slope edge assemblage, but increased strongly from the shelf-slope edge to the upper and middle slope communities (ANOVA: $F=19.77$; $\mathrm{p}<0.0001$, see Table 6).

\section{DISCUSSION}

The decapod crustacean fauna of the central Tyrrhenian presented a clear zonation effect with a series of well-defined bathymetric boundaries. The boundaries seemed to be connected with a variety of factors all related to depth (Macpherson, 1991).

The distribution of species depends on a number of environmental variables, such as temperature and food availability, which can affect both the maximum density attained and the extreme limits of their distribution. The species distribution is wider or narrower in function of physical changes and biotic interactions (Therborg, 1970). Although in this study depth appeared to be one of the main structuring factors for the spatial distribution of species, other environmental variables directly related to depth, such as sediment type and organic matter, could play an important role in the distribution of some taxa (Paguridae, Crangonidae, Astacidea, etc.) mainly linked to edafic factors, especially in the coastal area. In this study the second structuring factor seems to be a sedimentary aspect, which repre- 
sents a gradient of increasingly fine particles (fine silt and mud) in sediments (Emylianov and Schimkus, 1986). Sediment grain size, which is determined by hydrodynamic sorting mechanisms, and organic content are considered the second most influential characteristics that determine occupancy by marine benthos (Gray, 1981); this factor could be more important for benthic decapods. Changes in the degradation of organic matter with depth are also important, both in relation to the vertical downward drift through the water column (Wishner, 1980) and the organic matter on the slope (Carpine, 1970; Rowe, 1983). In the coastal zone, this factor could play an important role in the distribution pattern: a significant input of organic matter is brought by different rivers, and this contribution influenced the whole study area.

Cluster analysis showed five faunistic assemblages: the main ecological change in structure and composition of species assemblages occurred moving from the continental shelf to the slope. This zonation pattern of decapod crustacean fauna is similar to that observed in the north-west Mediterranean (Abelló et al., 1988) and other areas of the north Atlantic (Lagardère, 1973, 1977; Haedrich, 1975; Haedrich et al., 1980; Markle et al., 1988; Olaso, 1990; Fariña et al., 1997), but in our study we found a clear shelf-slope transition group, between 120 and $180 \mathrm{~m}$ depth, not observed in other areas.

Three main assemblages were detected along the continental shelf, which grouped coastal shelf, middle shelf and shelf-slope edge stations respectively. In the coastal zone, the analysis did not allow us to identify differences in the assemblage composition, despite the heterogeneity of environmental conditions due to the presence of eutrophic areas like those affected by the water from the Tiber River (central Latium) and other rivers, lagoons connected with the sea, seagrass meadows, etc. Most of the coastal stations were located on sandy-muddy bottoms characterized by a high sedimentation rate and usually interpreted as ecotonal habitats between the coastal sandy bottoms and the terrigenous muddy bottoms located offshore (Colloca et al., 2003).

The crustacean community on middle shelf soft bottoms is dominated by Brachyurans and hermit crabs with very abundant and frequent species like Liocarcinus depurator, Goneplax rhomboides, Medorippe lanata, Pagurus prideaux and P. excavatus. These species are linked more to sediment type and to the amount of suspended organic matter
(Vernberg and Vernberg 1983; Rufino et al., 2004). Sediment characteristics have been found to strongly influence occurrence and distribution of many benthic decapod crustaceans, especially those with burrowing and burying habits (Atkinson and Taylor, 1988; Pinheiro et al., 1996; Comeau et al., 1998). The dominance of benthic crustaceans mainly preying on benthos resources (Cartes and Abelló, 1992; Cartes, 1998) is probably due to benthos resources being more important as a food-source in shelf communities, which agrees with a generally recognized decrease in benthos biomass with depth (Rowe, 1983).

The shelf-slope transition, at depths between 120 and $170 \mathrm{~m}$, is characterized by detritic organogenic sediments colonized by the crinoid Leptometra phalangium, a suspension-feeding macro-epibenthic species confined in the Mediterranean to the shelfbreak area (Colloca et al., 2003). Its abundance in the studied area can reach $12-15$ ind. $\mathrm{m}^{-2}$. Two characteristic species in this transition zone, Parapenaeus longirostris and Macropipus tuberculatus, showed a wide bathymetric distribution that covered both the upper shelf and the slope.

Within the shelf and slope assemblages, the occurrence of species reaching higher concentrations over a restricted depth range determined the occurrence of distinguishable assemblages at a lower dissimilarity level.

On the upper slope, Brachyura and Paguridae are replaced by several groups of Decapoda Natantia, Macrura (N. norvegicus, Polycheles typhlops) and Galatheidae (e.g. Munida intermedia). The only brachyuran species reaching significant abundance on the upper slope is M.tuberculatus.

The transition between upper-slope fauna and a strictly bathyal fauna appeared to be located at about $450 \mathrm{~m}$. The upper slope assemblage can be considered as transitional towards the bathyal environment where a well defined demersal community exists. The upper-slope was dominated by the pink shrimp $P$. longirostris and the Norway lobster $N$. norvegicus together with three species of pandalid shrimp: Plesionika heterocarpus, P. antigai and P. gigliolii. The middle slope is characterized by Aristaeidae and by the substitution within pandalid shrimps by the two deepest, $P$. martia and $P$. acanthonotus (Carbonell and Abelló 1998; Fanelli et al., 2004). The observed differences in the distribution of decapod crustaceans on the slope seem to be strongly linked to the depth gradient which may affect changes in other environmental factors such as sed- 
iments, benthic communities, light intensity, etc. (Gaertner et al., 1999). Maynou et al. (1996) showed that depth-related zonation of decapod crustaceans is complemented by a significant horizontal component that reflects a strong two-dimensional spatial heterogeneity. Abundant species like Pandalidae and Aristeidae shrimps and N. norvegicus (Abelló et al., 1988, 2002; Cartes and Sardà 1993; Maynou and Sardà 1997; Maynou et al., 1998; Fanelli et al., 2004) have a patchy distribution related to geomorphology (e.g. canyons), sediment re-suspensions and other factors that may increase local production and food availability (Cartes and Sardà, 1993; Cartes, 1994; Maynou et al., 1996).

Available data are not sufficient to show the effect of other oceanographic conditions on the distribution pattern of decapod crustacean species on the slope. Nevertheless, Fanelli and Cartes (2004) in the Alboran Sea observed a strong influence of some environmental variables (primary production 4 and 6 weeks before the sampling, hour of sampling in addition to depth) on some biological aspects and the pattern distribution of abundance of two dominant pandalid shrimps, $P$. martia and P. heterocarpus.

In the Mediterranean Sea the temperature does not change significantly below $150 \mathrm{~m}$ depth and therefore it may affect species distribution only on the shelf. In this region Gaertner (2000) observed a high persistence of fish assemblages during the year despite the seasonal changes in temperature, thus excluding any effect of this factor on the species distribution. Salinity in the western Mediterranean Sea shows changes due to the occurrence of a layer of Levantine Intermediate Water along the slope between 250 and $700 \mathrm{~m}$ depth (Serravall and Cristofalo, 1999). The effect of these depth-related differences in salinity on species distribution is currently unknown even though Abelló et al. (1988) hypothesized that salinity can play a structuring role for crustacean decapod communities. The differences in hydrological conditions between the shelf (high variability) and the slope (stability) can be interpreted as being responsible for the strong differences in the composition and structure of the demersal fauna in these two regions. Deep-water species are competitive in oligotrophic waters and adapted to restricted ranges of environmental parameters (temperature, salinity, light) (Ghidalia and Burgois, 1961; Maynou and Cartes, 2000), and may not be able to survive in a more heterogeneous environment such as the shelf. In the same way, shelf species are confined to this region as they are not able to compete and adapt to the stable environmental conditions of the slope.

Crustacean diversity appeared to be affected by the depth increasing significantly from the continental shelf to the middle slope. The lowest diversity and species richness values were observed on the shelfbreak where only two species of euribathic decapods, $M$. tuberculatus and P. longirostris, dominated the assemblage. This decrease in diversity on the shelfbreak can be attributed to the disappearance of typical shelf species, firstly brachyuran and hermit crabs, which are not replaced by slope species.

The greater environmental stability of the slope zone allows a more mature and thus more diverse community to develop (Sanders, 1968; Sanders and Hessler, 1969). The amplitude of seasonal temperature fluctuations decreases with depth. In addition, the occurrence of steep bottoms in this area favours the co-existence of pelagic (e.g. Pasiphaea spp.) and nektobenthic species (Aristaeidae and Pandalidae), which are relatively independent of benthic resources, with the strictly benthic species, resulting in increased diversity.

This study provides useful information about the composition and distribution of decapod fauna in an oligotrophic and over-exploited area. Further investigations should be devoted to analyzing species relationships and resource partitioning between species to better understand the dynamic of crustacean assemblages exposed to fishing exploitation.

\section{ACKNOWLEDGEMENTS}

The authors wish to thank Dr. Joan E. Cartes for his helpful suggestions, Ms. T. Schoolmester who revised the English and the anonymous referees who helped us to improve the early version.

\section{REFERENCES}

A.A.V.V. - 1985. Atlante delle spiagge italiane. F. 132, 135.P.F. Conservazione del suolo, Sottoprogetto Dinamica dei litorali, C.N.R.

Abelló, P., F.J. Valladares and A. Castellón. - 1988. Analysis of the structure of decapod crustacean assemblages off the Catalan coasts (North-West Mediterranean). Mar. Biol., 98: 39-49.

Abelló, P., A. Carbonell and P. Torres. - 2002. Biogeography of epibenthic crustaceans on the shelf and upper slope off the Iberian Peninsula Mediterranean coasts: implications for the establishment of natural management areas. Sci. Mar., 66 (Suppl. 2): 183-198.

Arena, P. and F. Li Greci. - 1973. Indagine sulle condizioni faunis- 
tiche e sui rendimenti di pesca dei fondali batiali della Sicilia occidentale e della bordura settentrionale dei banchi della soglia Siculo-Tunisina. Quad. Lab. Tecnol. Pesca, 1: 157-201.

Atkinson, R.J.A. and A.C. Taylor. - 1988. Physiological ecology of burrowing decapods. In: A.A. Fincham and P.S. Rainbow (eds.), Aspects of decapod crustacean biology, pp. 201-226. Symp. Zool. Soc. Lond. Vol 59.

Bellotti, P. and P. Tortora. - 1985. Il delta del Tevere: lineamenti batimetrico, morfologici e tessiturali della conoide sommersa e delle aree limitrofe. Boll. Soc. Geol. It., 104: 65-80.

Bertrand, J. A., L. Gil de Sola, C. Papaconstantinou, G. Relini and A. Souplet. - 2002. The general specifications of the MEDITS survey. Sci. Mar., 66(Suppl. 2): 9-17.

Biagi, F., P. Sartor, G.D. Ardizzone, P. Belcari, A. Belluscio and F. Serena. - 2002. Analysis of demersal assemblages off the Tuscany and Latium coasts (North-Western Mediterranean). Sci.Mar., 66(Suppl. 2): 233-242

Blanchard, F. - 2001. Un approche de la dynamique des peuplements de poissons démersaux exploite`s: analyse comparée de la diversité spécifique dans le golfe de Gascogne (Océan Atlantique) et dans le golfe du Lion (mer Méditerranée). Aquat. Living Resour., 14: 29-40.

Carbonell, A. and P. Abelló. - 1998. Distribution characteristics of pandalid shrimps (Decapoda: Caridea: Pandalidae) along the western Mediterranean Sea. J. Nat. Hist. 32: 1463-1474.

Carpine, C. - 1970. Écologie de l'étage bathyal dans la Méditerranée occidentale. Mem. Inst. Océanogr. Monaco, 2: 1-146.

Cartes, J.E. - 1993. Deep-sea decapod fauna of the Western Mediterranean: Bathymetric distribution and biogeographic aspects. Crustaceana, 65: 29-40.

Cartes, J.E. - 1994. Influence of depth and season on the diet of the deep-water aristeid Aristeus antennatus along the continental slope (400-2300 m) in the Catalan Sea (western Mediterranean). Mar. Biol., 120: 639-648.

Cartes, J.E. - 1998. Feeding strategies and partition of food resources in deep-water decapod crustaceans in relation to depth (between 400-2300 m). J. Mar. Biol. Ass. UK, 78: 509-524.

Cartes, J.E. and P. Abelló. - 1992. Comparative feeding habits of polychelid lobsters in the western Mediterranean. Mar. Ecol. Prog. Ser., 84: 139-159

Cartes, J.E. and F. Sardà. - 1993. Zonation of the deep-sea decapod fauna in the Catalan Sea (Western Mediterranean). Mar. Ecol. Prog. Ser., 94: 27-34.

Cartes, J.E., J.B. Company and F. Maynou. - 1994. Deep-water decapod crustacean communities in the northwestern Mediterranean: influence of submarine canyons and season. Mar. Biol., 120: 221-229.

Chiocci, F.L. and G.B. La Monica - 1999. Individuazione e caratterizzazione dei depositi sabbiosi presenti sulla piattaforma continentale della Regione Lazio e valutazione di un loro utilizzo ai fini del ripascimento dei litorali in erosione. Università degli Studi di Roma "La Sapienza", Dip.to Sc. Della Terra, Assessorato Opere e Reti di Servizio e mobilità. Final Report Phase I.

Clarke, K.R. - 1993. Non-parametric multivariate analyses of changes in community structure. Aust. J. Ecol., 18: 117-143.

Clarke, K.R. and R.M. Warwick. - 1994. Change in marine communities: an approach to statistical analysis and interpretation. Nat. Env. Res. Counc. UK, 144 pp.

Colloca, F., M. Cardinale, A. Belluscio and G.D. Ardizzone - 2003. Pattern of distribution and diversity of demersal assemblages in the central Mediterranean sea. Est. Coast. Shelf Sci., 56: 469-480.

Comeau, M., G.Y. Conan, F. Maynou, G. Robichaud, J.C. Therriault and M. Starr. - 1998. Growth, spatial distribution, and abundance of benthic stages of the snow crab (Chionoecetes opilio) in Bonne Bay, Newfoundland, Canada. Can. J. Fish. Aquat. Sci. 55: 262-279.

Emylianov, E.M. and K.M Schimkus. - 1986. Geochemistry and sedimentology of the Mediterranean Sea. Dordrecht D. Reidel.

Fanelli, E. and J.E. Cartes. - 2004. Feeding habits of pandalid shrimps in the Alboran Sea (SW Mediterranean): influence of biological and environmental factors. Mar. Ecol. Prog. Ser., 280: $227-238$

Fanelli, E., A. Belluscio, F. Colloca and G.D. Ardizzone. - 2004. Distribution characteristics of pandalid shrimps (Decapoda: Caridea: Pandalidae) along the central Mediterranean sea. Medit.Mar.Sci., 5(2): 35-43.
Fariña, A.C., J. Freire and E. González-Gurriarán. - 1997. Demersal fish assemblages in the Galician continental shelf and upperslope (NW Spain): spatial structure and long-term changes. Est. Coast. Shelf Sci., 44: 435-454.

Gaertner, J.C., N. Mazouni, R. Sabatier and B. Millet. - 1999. Spatial structure and habitat associations of demersal assemblages in the Gulf of Lions: a multicompartmental approach. Mar. Biol., 135: 199-208.

Gaertner, J.C. - 2000. Seasonal organization patterns of demersal assemblages in the Gulf of Lions (north-west Mediterranean Sea). J. Mar. Biol. Ass. UK, 80: 777-783.

Ghidalia, W. and F. Burgois. - 1961. Influence of temperature and light on the distribution of shrimps in medium and great depths. Gen. Fish. Counc. Med., Stud. and Rev., 16: 1-49.

Gray, J.S. - 1981. The ecology of marine sediments. Cambridge studies in modern biology 2. Cambridge University Press, Cambridge.

Greenstreet, S.P.R. and S.J. Hall. - 1996. Fishing and the ground-fish assemblage structure in the north-western North Sea: an analysis of long-term and spatial trends. J. Anim. Ecol., 65: 577-598.

Haedrich, R.L. - 1975. Zonation and faunal composition of epibenthic populations of the continental slope south of New England. J. Mar. Res., 33: 191-212.

Haedrich, R.L., G.T. Rowe and P.T. Polloni. - 1980. The megabenthic fauna in the deep sea south of New England, USA. Mar. Biol., 57: 165-179.

Hill, M.O. - 1973. Diversity and evenness: a unifying notation and its consequences. Ecology, 54: 427-432.

IFREMER. - 1997. Medatlas. Mediterranean Hydrological Atlas (CD rom). IFREMER edition, Brest, France.

Lagardère, J.P. - 1973. Distribution des décapodes dans le sud de Golfe de Gascogne. Rev. Trav. Inst. Pêch. Marit, 37: 77-95.

Lagardère, J.P. - 1977. Recherches sur la distribution verticale et sur l'alimentation des crustaces decapodes benthiques de la Pente Continentale du Golfe de Gascogne. Analyse des groupements carcinologiques. Bull. Cent. Étud. Rech. Scient. Biarritz, 11: 367-440.

Macpherson, E. - 1991. Biogeography and community structure of the decapod crustacean fauna off Namibia (southeast Atlantic). J. Crust. Biol., 11: 401-415.

Markle, D.F., M.J. Dadswell and R.G. Halliday. - 1988. Demersal fish and decapod crustacean fauna of the upper continental slope off Nova Scotia from la Havre to St. Pirre Banks. Can. J. Zool., 66: 1952-1960.

Maynou, F., G.Y. Conan, J.E. Cartes and J.B. Company. - 1996. Spatial structure and seasonality of decapod crustacean populations on the North western Mediterranean slope. Limnol. Oceanogr., 41: 113-125.

Maynou, F. and F. Sardà. - 1997. Nephrops norvegicus population and morphometrical characteristics in relation to substrate heterogeneity. Fish. Res., 30(1): 139-149.

Maynou, F., F. Sardà and G. Conan. - 1998. Assessment of the spatial structure and biomass evaluation of N. norvegicus (L.) populations in the Northwestern Mediterranean by Geostatistics. ICES J. Mar. Sci., 55: 102-120.

Maynou, F. and J.E. Cartes. - 2000. Community structure of bathyal decapod crustaceans off south-west Balearic Islands (western Mediterranean): seasonality and regional patterns in zonation. J. Mar. Biol. Ass. UK, 80: 789-798.

Olaso, I. - 1990. Distribución y abundancia del megabentos invertebrado en fondos de la plataforma cantabrica. Publ. Inst. Esp. Oceanogr., Madrid, 5: 1-128.

Pinheiro, M.A.A., A. Fransozo and M.L. Negreiros-Fransozo. 1996. Distribution patterns of Arenaeus cribarius (Lamarck, 1818) (Crustacea, Portunidae) in Fortaleza Bay, Ubatuba (SP), Brazil. Rev. Bras. Biol., 56: 705-716.

Relini, G. - 1981. Campagna di pesca a strascico 1977 sui fondi batiali del Mar Ligure nell'ambito dei programmi finalizzati. Quad. Lab. Tecnol. Pesca, 3: 111-122.

Relini, G., A. Peirano and L. Tunesi. - 1986. Osservazioni sulle comunità dei fondi strascicabili del Mar Ligure centroOrientale. Mem. Ist. Biol. Univ. Genova, 52: 139-161.

Reyss, D. - 1971. Les canyons sous-marins de la mer Catalane: le rech. du Cap et le rech. Lacaze-Duthiers. III. Les peuplements de macrofaune benthique. Vie Milieu, 22: 529-613.

Rowe, G.T. - 1983. Biomass and production of the deep-sea macrobenthos. In: G.T. Rowe (ed.), Deep-sea Biology: The sea, Vol. 8, pp. 97-121. Wiley, New York.

Rufino, M.M., F. Maynou, P. Abelló and A.B. Yule.- 2004. Small- 
$28 \cdot$ E. FANELLI et al.

scale non-linear geostatistical analysis of Liocarcinus depurator (Crustacea: Brachyura) abundance and size structure in a western Mediterranean population. Mar. Ecol. Prog. Ser., 276: 223-235.

Sanders, H.L. - 1968. Marine benthic diversity: a comparative study. Am. Nat., 102: 243-282.

Sanders, H.L. and R.R. Hessler. - 1969. Ecology of deep-sea benthos. Science N.Y., 63: 1419-1424.

Sardà, F., J.E. Cartes and J.B. Company. - 1994. Spatio-temporal variations in megabenthos abundance in three different habitats of the Catalan deep-sea (western Mediterranean). Mar. Biol., 120: 211-219.

Serravall, R. and G.C. Cristofalo. - 1999. On the presence of a coastal current of Levantine intermediate water in the central Tyrrhenian Sea. Oceanol. Acta, 22: 281-290.

Therborg, J. - 1970. Distribution on environmental gradients: Theory and a preliminary interpretation of distributional patterns in avi- fauna of the Cordillera Vilcabamba, Perù. Ecology, 52: 23-40.

Tortora, P. - 1989. I fondali antistanti la costa di Montalto di Castro (alto Lazio): caratteristiche ed evoluzione tardo-quaternaria. Il Quaternario, 2(2): 175-187.

Tunesi, L. - 1986. Crostacei decapodi dei fondi strascicabili antistanti Chiavari (Riviera ligure di Levante). Ann. Mus. Civ. Storia Nat. Giacomo Doria, 86: 29-44.

Vernberg, F.J. and W.B. Vernberg. - 1983. The biology of Crustacea . Environmental adaptions, Vol 8. Academic Press, New York.

Wishner, K.F. - 1980. The biomass of the deep-sea benthopelagic plankton. Deep Sea Res., 27: 203-216.

Scien. ed.: P. Abelló

Received November 7, 2005. Accepted July 25, 2006.

Published online January 23, 2007. 